\title{
Лабораторно-польові дослідження ефективності впливу сортування насіння за розмірами на урожайність сафлору
}

\author{
М.В. Бакум ${ }^{1}$, М.М. Крекот ${ }^{2}$, А.Д. Михайлов ${ }^{3}$, О.Б. Козій ${ }^{4}$, \\ М.М. Майборода ${ }^{5}$, В.К. Пузік ${ }^{6}$, О.С. Чалая ${ }^{7}$, \\ В.В. Безпалько ${ }^{6}$, О.В. Панкова ${ }^{8}$, В.О. Гробов \\ Харківський національний технічний університет сільського господарства \\ ім. Петра Василенка (м. Харків, Україна), \\ email: ${ }^{1 b a k y m s h m @ k h n t u s g . i n f o, ~}{ }^{2}$ krekotshm@khntusg.info, ${ }^{3}$ kafedrashm@khntusg.info, \\ 4koziyabshm@khntusg.info, 5mashabakum@khntusg.info,6agroecology265@khntusg.info, \\ 7chalaia.olha@khntusg.com,8pankova_oksana@khntusg.info
}

\begin{abstract}
Однією з перспективних культур для посушливих умов сходу України $є$ сафрлор красильний. Але технологія його вирощування в Україні розроблена недостатньо. Немає чітких рекомендацій виробництву за термінами, способами, нормами посіву та вимогами до посівного матеріалу, в тому числі і до фракційного складу насіння культури. Сортування насіннєвого матеріалу за розмірами відома складова підготовки високоякісного посівного матеріалу, ефективність впливу якої на урожайність сафрлору вивчена ще не в повній мірі.

Для визначення закономірності формування продуктивності сафлору красильного в залежності від розмірів висіяного насіння виконані лабораторно - польові дослідження.

Для перевірки впливу розмірів насіння на врожайність сафлору відсортовані три фракції: велике насіння (сходова фрракція решета з круглими отворами діаметром 5,0 мм, яка становила 18,24\% від маси вихідного матеріалу), середнє (сходова фрракція решета з прямокутними отворами шириною 3,0 мм, яка становила $58,21 \%$ від маси вихідного матеріалу), дрібне (проходова фракція решета з прямокутними отворами шириною 3,0 мм, яка становила 23,55\% від маси вихідного матеріалу).

На основі показників росту і розвитку, структури врожаю та врожайності, що були отримані при вирощуванні насіння сафлору різного фракційного складу, встановлено, що найбільш оптимальним є використання у сівбі середньої фракції насіння сафлору. Таке насіння мало найбільший показник врожайності, при достатньо високих показниках росту і продуктивних якостей та найкращий показник виживаємості рослин.
\end{abstract}

Ключові слова: насіння сафрлору, сортування, розміри, решето, посівний матеріал, врожайність.

Вступ. Важливим напрямком сільського господарства є виробництво рослинної олії, світове споживання якої в останні роки істотно зростає. Україна за своїм географрічним положенням і кліматичними умовами є одним з основних виробників олії насіння соняшнику, що зумовлює щорічне зростання його посівів. Тому площі, зайняті в Україні під соняшником, уже тепер в декілька разів перевищують науково-обґрунтовані. При цьому інтерес виробників до інших олійних культур обмежується недостатньою обґрунтованістю їх вирощування. Це змушує вести пошук альтернативних олійних культур для різних ґрунтово-кліматичних зон України. Однією з таких перспективних культур для посушливих умов сходу України $€$ сафрлор красильний (Carthamus tinctorius L) [1].

Ця культура є привабливою для землеробів, перш за все, своєю посухостійкістю та невибагливістю до ґрунтових показників. Сафлор добре росте навіть на солонцюватих та засолених ґрунтах в умовах степу та полупустелі. До того ж сафлор не так інтенсивно, як соняшник, виснажує ґрунти, не потребує застосування агрохімікатів та спеціальних агротехнологій.

Враховуючи стійку тенденцію сучасного клімату до змін з часто виникаючими погодними аномаліями на фоні росту показників середньорічних температур, що негативно відображаються на врожайності більшості інших сільськогосподарських культур, такі якості сафрлору вигідно відрізняють його від традиційних для України олійних культур [2].

Крім того, сафрлор є багатоплановою культурою і використовується у багатьох галузях народного господарства. Так, сафрлор $є$ цінною кормовою культурою, і може згодовуватись тваринам в якості зеленої маси, сіна та силосу. Сафлорове сіно (неколючих сортів) за своєю поживністю не поступається люцерновому. Сафрлор є доброю медоносною культурою, а також має широке технічне 
застосування - при виготовленні оліфи, лаків, мила, косметичних засобів та фарб для тканин.

На сьогоднішній день сафлор на території України найбільше вирощується у Херсонській та Запорізькій областях, а ринок насіння сафлору знаходиться на етапі фрормування та направлений на експорт у країни Європи.

У світі найбільшими експортерами сафлору $є$ Росія (44\% світового експорту), Казахстан $(15,7 \%)$, Індія $(14,4 \%)$ та Нідерланди $(10,1 \%)$. Основними імпортерами є Туреччина (30\%), Китай (20\%), Швейцарія і Бельгія.

Технологія вирощування сафлору в Україні розроблена недостатньо. Немає чітких рекомендацій виробництву за термінами, способами, нормами посіву та вимогами до посівного матеріалу, в тому числі і до фрракційного складу насіння культури [2,3].

Постановка проблеми. На врожайність сільськогосподарських культур впливає багато чинників і одним з них $є$ використання у вирощуванні найякісніших фрракцій насіння. У різних культур та їх сортів розмір насіння, що визначає найбільшу насіннєву продуктивність може коливатися. Дослідження насіннєзнавців свідчать, що із збільшенням розмірів насіння, підвищується кількість зародкових корінців, рослини фоормуються міцнішими та характеризуються швидким проходженням етапів органогенезу [4].

Сортування насіннєвого матеріалу за розмірами - відома складова підготовки високоякісного посівного матеріалу, ефективність впливу якої на урожайність багатьох сільськогосподарських культур вивчена ще не в повній мірі.

Проведеними дослідженнями підтверджено зниження урожайності багатьох сільськогосподарських культур на $10 \ldots 12 \%$ при використанні посівного матеріалу з вмістом дрібного, щуплого недорозвиненого насіння. Найкращу врожайність забезпечує насіння добре сформоване, не щупле, але i не занадто велике, що має високу енергію проростання та силу росту. Дослідами також встановлено, що із насіння, яке проростає пізніше термінів, прийнятих для визначення енергії проростання, виростають рослини, що мають нищу продуктивність на $15 \ldots 22 \%$, а багато із них гинуть, не досягнувши плодоносності [5].

Мета роботи. Виявити закономірності формування продуктивності сафлору красильного в залежності від розмірів висіяного насіння та визначити оптимальний фракційний склад насіння цієї культури.

Результати досліджень. Вихідним матеріалом для лабораторно-польових досліджень була насіннєва суміш сафлору сорту Лагідний. До іiї складу входило 98,02\% насіння основної культури, від загальної маси вихідного матеріалу. Мертві домішки становили 0,71\%, обрушене насіння сафрлору - 0,71\%, а насіння інших культурних рослин було 108 шт/кг.

Для формування фракцій посівного матеріалу різних розмірів використовували насіннєочисну машину СМ - 0,15 з тихохідними коливними решетами налагоджену згідно обґрунтованої схеми очищення насіннєвої суміші сафрлору [6].

Результати сортування насіннєвого матеріалу сафлору на решетах з круглими отворами діаметром 5,0 мм і прямокутними отворами шириною 3,0 мм наведені в табл. 1.

Як видно з таблиці 1, до сходової фракції верхнього решета з круглими отворами діаметром 5,0 мм відокремилось 18,24\% від маси вихідного матеріалу, самого великого (крупного) насіннєвого матеріалу. В ньому насіння сафлору становило 97,72\% від маси фракції. Маса 1000 насінин сафлору цієї фракції - 44,35 г, що на 7,66 г більше маси 1000 насінин вихідного матеріалу. Але енергія проростання і схожість насіння цієї фракції на 15\% менша насіння сафлору вихідного матеріалу.

Проходова фракція решета з круглими отворами діаметром 5,0 мм додатково сортувалась на решеті з прямокутними отворами шириною 3,0 мм.

Таблиця 1. Результати сепарації насіннєвої суміші сафрлору на решетах

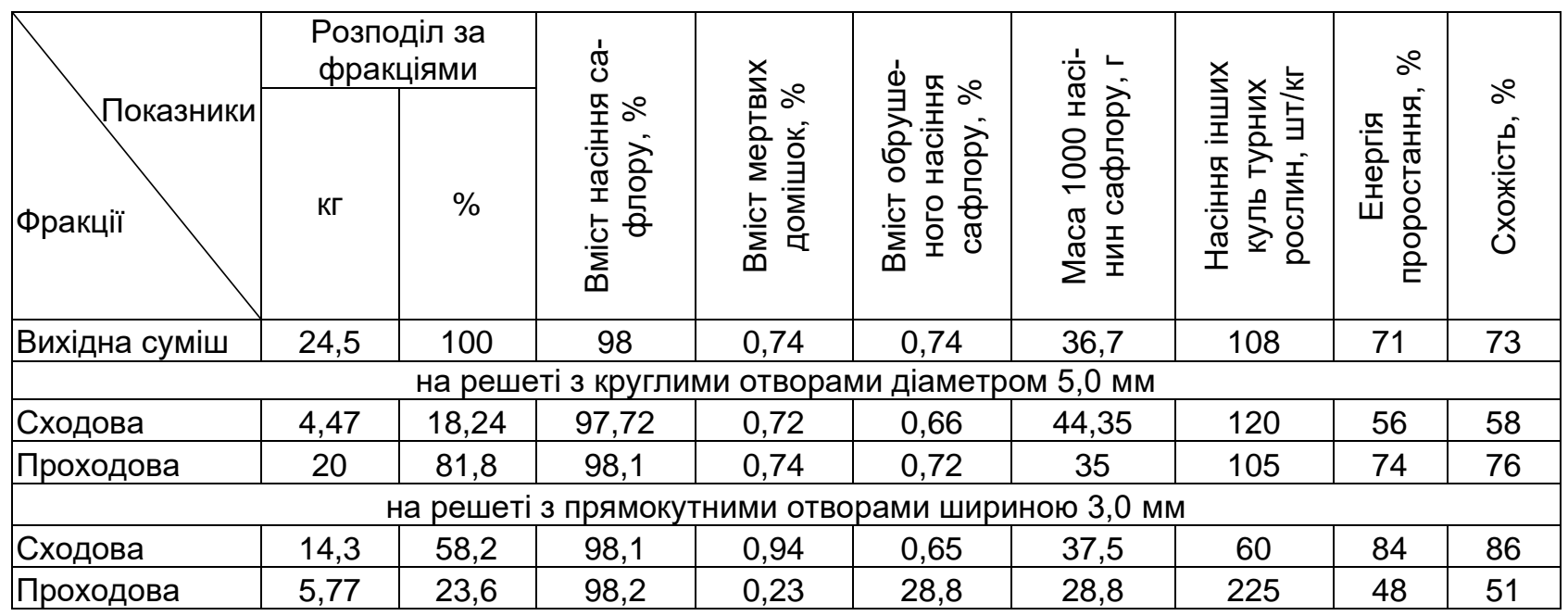


В проходову фракцію цього решета відсортувалось 23,55\% від маси вихідного матеріалу. Насіння сафлору в ній становило 98,18\% від маси фрракції. Маса 1000 штук насіння сафлору цієї фрракції - лише 28,75 г, що на 7,94 г менше насіння вихідного матеріалу. Його енергія проростання і схожість також менші від насіння вихідного матеріалу, відповідно, на $23 \%$ і $22 \%$.

Сходова фрракція решета з прямокутними отворами шириною 3,0 мм (найбільша за масою) становила $58,21 \%$ від маси вихідного матеріалу. Насіння сафрлору в ній становить 98,06\% від маси фрракції. Маса 1000 насінин цієї фракції на 0,81 г більша маси насінин вихідного матеріалу та на 8,75 г насіння проходової фракції, але на 6,85 г менша маси насіння сходової з решета 3 крупними отворами діаметром 5,0 мм. Енергія проростання і схожість насіння цієї фрракції самі великі і становлять $84 \%$ і $86 \%$, відповідно.

Польові дослідження проводилися у 2019 році в умовах навчально-дослідного поля кафедри агротехнологій та екології на базі НДП «Центральне» ХНТУСГ ім. П. Василенка. Об'єктом дослідження був районований сорт «Лагідний». Закладка дослідів проводилась із дотриманням вимог наукової агрономії. Повторність дослідів двократна, розміщення ділянок рандомізоване. Облікова площа дослідної ділянки $25 \mathrm{~m}^{2}$. Попередник - чорний пар.

У польовому досліді вивчали ріст, розвиток та продуктивність сафлору красильного в залежності від розмірів (фракційного складу) насіння (табл.1), а саме:

1 фрракція - велике насіння - схід решета 3 круглими отворами діаметром 5,0 мм;

2 фракція - середнє насіння - схід решета 3 прямокутними отворами шириною 3,0 мм;

3 фрракція - дрібне насіння - прохід решета 3 прямокутними отворами шириною 3,0 мм.

Польові дослідження, спостереження за фенологічними ознаками під час росту та розвитку рослин проводили у відповідності із загальноприйнятими методиками $[7,8]$.

Під час виконання польових досліджень 3 сафрлором, реєстрували настання основних фаз вегетації рослин: сходи, утворення корзинок, цвітіння, дозрівання. Динаміку росту рослин визначали шляхом проведення замірів при повному настанні фраз вегетації рослин, передчасно заекетованих рослин кожного дослідного варіанту, у тій же двократній повторності. 3 метою обліку продуктивності сафрлору за варіантами, проводили відбір проб рослин $31 \mathrm{~m}^{2}$ кожного повторення для кожного варіанту.

Сівбу виконували вручну, ширина міжрядь $45 \mathrm{~cm}$. Передпосівний обробіток ґрунту проводили на глибину загортання насіння до 4 см, насіння висівалось при температурі ґрунту $4,3 \ldots 4,8^{\circ} \mathrm{C}$, мінеральні добрива не вносились.
Величина врожаю залежить від двох показників - густоти продуктивного стеблостою та маси зерна з однієї корзинки, тому біологічну врожайність визначали за формулою:

$$
\mathrm{B}_{\text {біол }}=\Gamma \times \mathrm{m} \times 10000 / 100000
$$

Для цього на пробних ділянках розміром $1 \mathrm{~m}^{2}$ підраховували такі показники:

- густоту продуктивного стеблостою, шт./М² (Г); - масу зерна з одної корзинки, г (М);

Перед збиранням врожаю визначали густоту стояння рослин сафлору на різних дослідних ділянках і цей показник коливався від 16 до 24 шт./м². Було встановлено, що на ділянці де висівали дрібну фрракцію насіння, рослини були значно розріджені і на 1 метрі погонному розміщувалося в середньому 8 рослин, на ділянках з великим та середнім насінням цей показник відповідно становив 11 та 12 рослин. Таким чином, внаслідок низької схожості та виживання рослин 3 насіння дрібної фрракції відбулось їх розрідження i, як наслідок, збільшення площі живлення кожної рослини, порівняно із іншими дослідними ділянками. Це позитивно відобразилось на ростових і продуктивних показниках рослин цієї дослідної ділянки, однак негативно позначилось на загальних показниках врожайності.

Проведені дослідження по впливу фракційного складу насіння на продуктивні показники сафрлору красильного показали, що розмір насіння впливає як на морфологічні показники культури в процесі розвитку, так і на показники структури врожаю. Необхідно відмітити, що тривалість вегетаційного періоду від повних сходів до повної стиглості по всіх фракціях насіння була однакова і склала 116 діб.

Дослідження морфологічних показників сафлору красильного в залежності від фракційного складу насіння показали, що при появі сходів, на початковому етапі, між рослинами сафлору по всіх варіантах досліду особливих відмінностей за ростовими показниками не спостерігалось. У наступних фразах вегетаційного розвитку рослин відмічалось деяке відставання росту у посівах великої та середньої фракцій насіння у порівнянні з посівами дрібної фракції. Так, у фазі повної стиглості висота рослин дрібної фракції перевищувала показники великої та середньої, відповідно, на 11,1\% та 5,1\%. Більшими були і показники товщина стебла, довжини кореня та висоти закладки бічних пагонів (табл 2.)

Товщина стебла $є$ ознакою достатньої кількості всіх елементів живлення для рослини. Спостереженнями за посівами встановлено, що у рослин товщина стебла зростала із зменшенням розмірів фрракції насіння. Різниця у діаметрі стебла між фрракціями становила 1,0...0,5 мм (таблиця 2). Довжина коренів із зміною розмірів 
фракції насіння змінювалась не суттєво, а найбільшим цей показник був у рослин дрібної фракції. Поряд із змінами висоти рослин змінювався і показник висоти закладки бічних пагонів від 62,4 cм до 65,4 см. Висота закладки бічних пагонів була найбільшою серед рослин дрібної фрракції, що можна пояснити більшим показником висоти рослин для цієї дослідної групи.

Таблиця 2. Морфологічні показники сафлору красильного в залежності від розмірів фракції посівного матеріалу

\begin{tabular}{|c|c|c|c|c|}
\hline $\begin{array}{l}\text { Фракція } \\
\text { насіння }\end{array}$ & 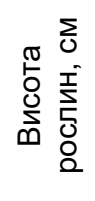 & 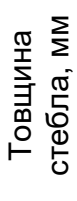 & 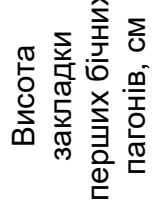 & 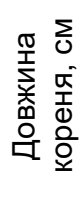 \\
\hline Велике & 75,9 & 5,9 & 63,1 & 13,2 \\
\hline Середнє & 80,25 & 6,4 & 62,4 & 13,0 \\
\hline Дрібне & 84,35 & 6,9 & 65,4 & 13,3 \\
\hline
\end{tabular}

В результаті проведеного експерименту встановлено, що розміри насіння впливають на структурні показники посівів, в тому числі на кількість корзинок та число зерен з однієї рослини і масу 1000 насінин (таблиця 3). Ці показники вплинули на біологічну врожайність сафлору.

Таблиця 3. Структура врожаю та врожайність сафрлору в умовах досліду

\begin{tabular}{|c|c|c|c|c|c|c|}
\hline \multirow[b]{2}{*}{$\begin{array}{l}\text { Фракція } \\
\text { насіння }\end{array}$} & \multicolumn{2}{|c|}{$\begin{array}{c}\text { Кількість кор- } \\
\text { зинок на } 1 \\
\text { рослині, шт. }\end{array}$} & \multirow{2}{*}{ 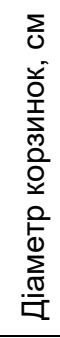 } & \multirow{2}{*}{ 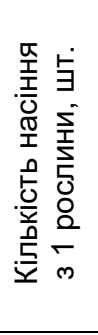 } & \multirow{2}{*}{ 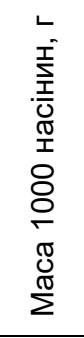 } & \multirow{2}{*}{ 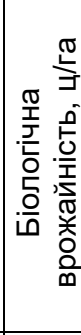 } \\
\hline & $\begin{array}{l}\text { 잉 } \\
\text { O } \\
0\end{array}$ & 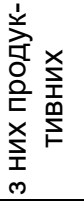 & & & & \\
\hline Велике & 6,7 & 5,9 & 2,4 & 165,1 & 38,7 & 3,5 \\
\hline Середнє & 7,6 & 7,1 & 2,4 & 172,0 & 39,0 & 4,4 \\
\hline Дрібне & 8,2 & 7,5 & 2,4 & 199,8 & 39,5 & 4,2 \\
\hline
\end{tabular}

3 даних таблиці 3 видно, що рослини дрібної фрракції мали найкращі показники структури врожаю (кількість продуктивних корзинок, кількість насіння з 1 рослини, маса 1000 насінин), але біологічна врожайність була нижчою, ніж у рослин середньої фракції. Це можна пояснити тим, що, як зазначалось раніше, рослини дрібної фракції мали розріджені посіви і показник густоти стояння, який значно впливає на рівень врожайності, був найменшим серед дослідних груп. Найменші показники структури врожаю та врожайності мали рослини великої фракції. Рослини середньої фракції, хоч і поступалися за цими показникам рослинам дрібної фракцій, але перевищили їх за врожайністю.
Висновки. Для перевірки впливу розмірів насіння на врожайність сафлору відсортовані три фрракції: велике насіння (сходова фрракція решета 3 круглими отворами діаметром 5,0 мм, яка становила 18,24\% від маси вихідного матеріалу), середнє (сходова фрракція решета з прямокутними отворами шириною 3,0 мм, яка становила 58,21\% від маси вихідного матеріалу), дрібне (проходова фрракція решета з прямокутними отворами шириною 3,0 мм, яка становила 23,55\% від маси вихідного матеріалу).

Враховуючи показники росту і розвитку, структури врожаю та врожайності, що були отримані при вирощуванні насіння сафлору різного фракційного складу, можна зробити висновок, що найбільш оптимальним є використання у сівбі середньої фрракції насіння сафллору.

Насіння середніх розмірів мало найбільший показник врожайності, при достатньо високих показниках росту і продуктивних якостей та найкращий показник виживаємості рослин.

\section{Література:}

1. Зінченко О.І. Рослинництво: підручник / О.І. Зінченко, В.Н. Салатенко, М.А. Білоножко. - К.: Аграрна освіта, 2001. - 591 с.

2. Філіпов Є.Г. Агротехнічні прийоми на економічну ефективність вирощування сафлору красильного в умовах зрошення півдня України / Bicник аграрної науки Причорномор'я . - 2014. - Вип. 2. - C. $143-149$.

3. Ушкаренко В.О. Вирощування сафлору на Півдні України: практичні рекомендації / В.О. Ушкаренко та інші. - Херсон. - 2012. - 28c.

4. Кузнецова Т.Е. Посевные качества и урожайные свойства семян озимого ячменя в зависимости от фракций посевного материала / Т.Е. Кузнецова, С.А. Левштанов, Н.В. Серкин, Р.P. Юсупов //Зерновое хозяйство России. 2012. № 13, C. 47-52.

5. Промышленное семеноводство / В.И. Анискин, А.И. Баторчук, Б.А. Весна и др.; Под ред. И.Г. Строны. - М.: Колос, 1980. - 287с.

6. Бакум М.В. Обгрунтування ефективності використання решітних сепараторів для підготовки посівного матеріалу сафлору / М.В. Бакум, М.М. Крекот, А.Д. Михайлов, А.Б. Козій, М.М. Майборода, В.К. Пузік, О.С. Чалая, О.І. Басов, М.В. Циба // Механізація сільськогосподарського виробництва: Вісник ХНТУСГ ім П. Василенка. Харків: ХНТУСГ, 2019. - вип. 198. - С.18-25.

7. Методика наукових досліджень в агрономії [текст]: навч. посіб. / О.Ф. Смаглій, Е.Р. Ермантраут та ін. - К.: «Центр навчальної літератури», 2013. -264 c.

8. Дослідна справа в агрономії: навч. посібник: у 2 кн. - Кн. 1. Теоретичні аспекти дослідної справи / А.О. Рожков, В.К. Пузік, С.М. Каленська та ін.; за ред. А.О. Рожкова. - Х.: Майдан, 2016. - 316 с. 


\section{References:}

1. Zinchenko O.I., Salatenko V.N. and Bilonozhko M.A. (2001) Roslynnytstvo: pidruchnyk. K.: Ahrarna osvita. $591 \mathrm{p}$.

2. Filipov Y.H. (2014) Ahrotekhnichni pryyomy na ekonomichnu efektyvnist' vyroshchuvannya safloru krasyl'noho $v$ umovakh zroshennya pivdnya Ukrayiny. Visnyk ahrarnoyi nauky Prychornomor'ya. (2). pp. $143-149$.

3. Ushkarenko V.O. et al. (2012) Vyroshchuvannya safloru na Pivdni Ukrayiny: praktychni rekomendatsiyi. Kherson. $28 \mathrm{p}$.

4. Kuznetsova T.Y., Levshtanov S.A., Serkin N.V. and Yusupov R.R. (2012) Posevnyye kachestva i urozhaynyye svoystva semyan ozimogo yachmenya v zavisimosti ot fraktsiy posevnogo materiala. Zernovoye khozyaystvo Rossii. (13). pp. 47-52.

5. Aniskin V.I. et al. (1980) Promyshlennoye semenovodstvo. M.: Kolos. $287 \mathrm{p}$.

6. Bakum M.V. et al. (2019) Obhruntuvannya efektyvnosti vykorystannya reshitnykh separatoriv dlya pidhotovky posivnoho materialu safloru. Mekhanizatsiya sil's'kohospodars'koho vyrobnytstva. Visnyk KHNTUSH im. P. Vasylenka. Kharkiv: (198). pp.18-25.

7. Smahliy O.F. et al. (2013) Metodyka naukovykh doslidzhen' $v$ ahronomiyi. navch. posibnyk. K.: «Tsentr navchal'noyi literatury». 264 p.

8. Rozhkov A.O. et al. (2016) Doslidna sprava v ahronomiyi. navch. posibnyk. Kn. 1. Teoretychni aspekty doslidnoyi spravy. Kharkiv: Maydan. 316 p.

\title{
Аннотация
}

\section{Лабораторно-полевые исследования эффективности воздействия сортировки семян по размерам на урожайность сафлора}

\author{
Н.В. Бакум, Н.Н. Крекот, А.Д. Михайлов, А.Б. Козий, М.Н. Майборода, \\ В.К. Пузик, О.С. Чалая, В.В. Беспалько, О.В. Панкова, В.А. Гробов
}

Одной из перспективных культур для засушливых условий востока Украины является сафрлор красильный. Но технология его выращивания в Украине разработана недостаточно. Нет четких рекомендаций производству по срокам, способам, нормам посева и требованиям к посевному материалу, в том числе и к фракционному составу семян культуры. Сортировка семенного материала по размерам - известная составляющая подготовки высококачественного посевного материала, эффективность влияния которой на урожайность сафлора изучена еще не в полной мере.

Для определения закономерности формирования продуктивности сафрлора красильного в зависимости от размеров высеянных семян выполнены лабораторно - полевые исследования.

Для проверки влияния размеров семян на урожайность сафрора отсортированы три фракции: крупные семена (сходовая фрракция решета с круглыми отверстиями диаметром 5,0 мм, которая составляла $18,24 \%$ от массы исходного материала), средние (сходовая фрракция решета с прямоугольными отверстиями шириной 3,0 мм, которая составляла $58,21 \%$ от массы исходного материала), мелкие (проходовая фрракция решета с прямоугольными отверстиями шириной 3,0 мм, которая составляла $23,55 \%$ от массы исходного материала).

На основе показателей роста и развития культуры, структуры урожая и урожайности, полученных при выращивании семян сафрлора различного фракционного состава, установлено, что наиболее оптимальным является использование в посеве средней фракции семян сафлора. Такие семена имели наибольший показатель урожайности, при достаточно высоких показателях роста и продуктивных качеств и лучший показатель выживаемости растений.

Ключевые слова: семена сафрлора, размер семян, сортировка, решето, посевной материал, урожайность.

\section{Abstract \\ Laboratory-field studies of the effectiveness of the impact of sorting seeds by size on the yield of safflower

\author{
M.V.Bakum, M.M. Krekot, A.D. Mikhailov, A.B. Koziy, M.N.Maiboroda,
} \\ V.K. Puzik, O.S. Chalaya, V.V. Bespalko, O.V. Pankova, V.A. Grobov}

One of the promising crops for the arid conditions of eastern Ukraine is dye safflower. But the technology of its cultivation in Ukraine has not been sufficiently developed. There are no clear recommendations for production on terms, methods, sowing rates and requirements for sowing material, including the fractional composition of crop seeds. Sorting of seed material by size is a well-known component of the preparation of highquality seed, the effect of which on safflower yield has not yet been fully studied.

To determine the regularities of the formation of the productivity of dye safflower, depending on the size of the sown seeds, laboratory - field studies were carried out. 
To check the effect of seed size on safflower yield, three fractions were sorted: large seeds (fraction coming off the sieve with round holes $5.0 \mathrm{~mm}$ in diameter, which was $18.24 \%$ of the starting material mass), medium (fraction coming off the sieve with round holes 3, $0 \mathrm{~mm}$, which accounted for $58.21 \%$ of the weight of the starting material), small (fraction passing through a sieve with rectangular holes $3.0 \mathrm{~mm}$ wide, which was $23.55 \%$ of the weight of the starting material).

Based on the growth and development indicators of the crop, the structure of the yield and the yield obtained when growing safflower seeds of various fractional composition, it was found that the most optimal is the use of the middle fraction of safflower seeds in sowing. Such seeds had the highest yield rate, with sufficiently high growth rates and productive qualities, and the best rate of plant survival.

Keywords: safflower seeds, seed size, sorting, sieve, sowing material, yield.

\section{Бібліографічне посилання/ Bibliography citation: Harvard}

Bakum, M. V. et al. (2020) 'Laboratory-field studies of the effectiveness of the impact of sorting seeds by size on the yield of safflower', Engineering of nature management, (3(17), pp. 35 - 40.

Подано до редакції / Received: 09.09.2020 